\title{
HIF-1alpha Inhibitor PX-478
}

National Cancer Institute

\section{Source}

National Cancer Institute. HIF-1alpha Inhibitor PX-478. NCI Thesaurus. Code C70953.

An orally active small molecule with potential antineoplastic activity. Although its mechanism of action has yet to be fully elucidated, HIF1-alpha inhibitor PX-478 appears to inhibit hypoxia-inducible factor 1-alpha (HIF1A) expression, which may result in decreased expression of HIF1A downstream target genes important to tumor growth and survival, a reduction in tumor cell proliferation, and the induction of tumor cell apoptosis. The inhibitory effect of this agent is independent of the tumor suppressor genes VHL and p53 and may be related to derangements in glucose uptake and metabolism due to inhibition of glucose transporter-1 (Glut-1). 